Eric C.A. Kaarsemaker

\title{
Employee Share Ownership as Moderator of the Relationship between Firm-Specific Human Capital Investments and Organizational Commitment ${ }^{* *}$
}

Tight labour markets and changing employment relationships make employees with high levels of firm-specific knowledge, skills, and abilities less dependent on and committed to their employer. Companies need to work harder in order to attract and retain employees and protect their mutual human capital investments. Using a dataset with survey data from employees in 11 companies $(N=777)$, the present study shows evidence that employee share ownership, provided that it is taken seriously as reflected by the presence of a small number of other HRM practices in the company, might be a worthwhile avenue for managers to explore.

Key words: human resource management, employee share ownership, organizational effectiveness, firm-specific investments

* Eric C.A. Kaarsemaker, University of York, The York Management School, Heslington, York YO10 5DD, UK. E-mail: e.kaarsemaker@gmail.com.

** Article received: October 16, 2008

Revised version accepted after double blind review: November 15, 2008. 


\section{Introduction}

I recently visited a relatively young, small and specialized mechanical engineering technology company to talk to employees about their thoughts on the founder and CEO's plan to implement an employee share ownership scheme. All of the employees I talked to had engineering degrees, most of them at the university level. Some even had a $\mathrm{PhD}$. The founder and CEO considered that sharing ownership with the employees would motivate them to stay with the company and would attract new employees in a currently very tight labour market for this type of engineers. Only by attracting and retaining the right employees could the company follow its growth strategy.

Without exception, the employees were positive about the idea of implementing an employee share ownership scheme in the company. Consistent with this, the workforce also appeared to have an already relatively high sense of ownership. This was particularly so for the employees who had been with the company the longest. However, in contrast, they appeared to have only very low levels of commitment to the company. Some of them had been thinking of leaving, maybe even to start their own company. They felt that it would not be difficult for them to leave the company and either start for themselves or find a similar job elsewhere. But at the same time, they felt they had invested a significant amount of time and energy in the company already, and they would prefer a situation in which they would have the opportunity to become co-owners of the company. They liked the idea of becoming co-owners not simply for financial reasons, but in particular because they also wanted more influence.

All else being equal, employees, as they are involved in work and in the organization they work for, develop feelings of ownership (Pierce/Kostova/Dirks 2001, 2003). These feelings can be aimed towards for example their work, their job, and the organization they work for as a whole. Employees invest time and energy and often they acquire knowledge, skills, and abilities that have less use or no use at all beyond the organization they currently work for. This kind of knowledge, skills, and abilities is usually referred to as "firm-specific," as they have less or no value in other organizations. The value to the company is usually high, though, and employees with this kind of knowledge, skills, and abilities are not easy to replace. It is therefore worrisome for organizations if employees do not feel that their firm-specific knowledge, skills, and abilities make it more difficult for them to leave.

This paper analyzes the influence that employee share ownership has on the effects of "investments in firm-specific human capital." The analysis answers the question whether employee share ownership is an effective vehicle for converting feelings of ownership into actual commitment to the organization, and for attracting and retaining employees with firm-specific knowledge, skills, and abilities in the affirmative. In other words: within the limitations of the data, the paper's findings confirm that employee share ownership helps retain employees with highly firm-specific knowledge, skills, and abilities and therefore helps warrant further investments in firmspecific human capital. Employee share ownership might therefore be helpful in solving labour market issues that companies such as the engineering company in the example have. Apart from this practical implication, the paper also adds to employee 
share ownership research and research on firm-specific human capital, as the two have hardly been researched together in empirical research.

The next section starts with a theoretical discussion. The rest of the paper describes empirical tests using data from employees $(N=777)$ in 11 (mainly) professional services firms: 289 employees in 3 companies without employee share ownership, and 488 employees in 8 companies with employee share ownership, including 283 employee shareholders.

\section{Theory: Employee share ownership and firm-specific human capital}

\subsection{Employee share ownership}

\section{Definition}

Employee share ownership has many appearances. Hence it needs clarification what is meant by it here. It most commonly refers to employee share ownership plans, or ESOPs. An ESOP usually consists of a trust that a company sets up to administer the plan and its regulations. This involves for example the administration of the employees' accounts, the organization of regular trading opportunities (in case a company is not listed) and often trustees vote on behalf of the employee owners. This setup and the plan regulations can differ significantly between companies. Legislation plays an important role as well. Also, the presence of an ESOP does not everywhere and always mean that all employees are eligible to participate, or that all eligible employees in fact do participate. A yet different issue is the size of the employee shareholdings, individually, and collectively - some companies are 100 percent employee-owned, whereas in others the workforce holds only a small stake. Finally, plans do not always involve actual shares - often, they involve share options, phantom stock or other derivatives. The present study is limited to ESOP-type employee share ownership, i.e., plans that involve shares or share certificates, administered by a trust.

\section{Incidence}

The incidence of employee share ownership differs significantly per country. In the United States it is probably most common. The most recent estimates of the incidence there show 9,774 ESOPs with no less than 11.2 million participants. ${ }^{1}$ Estimates for the UK show more than 2,000 plans covering about 3 million employees (CIPD 2006). In other countries the phenomenon, though less common, has expanded as well. In Germany for example, the most recent estimates show that the incidence of several types of employee share ownership has grown to 4,125 plans, involving 2.4 million workers. ${ }^{2}$ However, the German estimates represent significantly less money value than the US and UK estimates.

\section{Effects}

Since the 1970s, when legislation was introduced in the US and the UK to support employee share ownership, over 130 quantitative academic studies on the effects of

See http://www.nceo.org, February 2008 estimates by the NCEO.

2 See http://www.agpev.de, January 2008 estimates by the AGP/GIZ. 
employee share ownership have appeared (Kaarsemaker 2006). Syntheses of this research have shown that straightforward negative effects on employee-level and company-level outcomes have not often been found, but positive effects do not always and automatically come about either (Conte/Svejnar 1990; Kaarsemaker 2006; Kruse 2002; Kruse/Blasi 1995). Relevant to the present study, previous research has found mixed associations with organizational commitment (e.g., Bakan et al. 2004; Culpepper/Gamble/Blubaugh 2004; Pendleton 2001; Sengupta/Whitfield/McNabb 2007). Several contextual variables seem to play an important role here, which has also been shown by a small minority of the quantitative studies and various qualitative studies. Examples of these contingencies are other HRM practices such as participation in decision-making practices, traits and characteristics of the people involved, managerial attitudes and behaviour, the business strategy and market context, organizational characteristics such as organizational heritage, industry, size, and organizational life cycle stage, and the institutional/legal context (e.g., De Jong/Van Witteloostuijn 2004; Maaløe 1998; Rosen/Case/Staubus 2005). Only a minority of quantitative studies have included contextual variables such as these and shown their relevance (e.g., Blasi/Conte/Kruse 1996; Blasi et al. 2008; Kalmi/Pendleton/Poutsma 2005; Pendleton 2001).

\section{Psychological ownership}

Following Pierce et al. (2001, 2003), the effects of employee share ownership are assumed to root in a number of human motives: (1) the need to exercise influence over the environment; (2) the need for self-identification; and (3) the need to have a place of oneself. Through its fulfilment of human motives such as these, employee share ownership facilitates the development of feelings of ownership towards an organizational factor such as one's work, or towards the company as a whole. This psychological ownership stems from the amount of control employees have over the particular organizational factor that is the target of the ownership feelings, the intimate knowledge about the target that employees acquire in the course of time, and employees' levels of self-investment in the target (Pierce et al. 2001, 2003). For example, mechanical engineers in a small and specialized technology company work with and develop further their company's latest simulation software to test the strength of new materials they have developed for advanced industrial machinery. These engineers are doing creative and innovative work. They have significant discretion in applying their own knowledge and ideas, and accordingly show high levels of self-investment, and feelings of ownership.

\section{Human resource management}

Employee share ownership is basically about "ownership." Owners of an asset generally have the right to use it in any way they like, the right to its returns, and the right to sell the asset. For employee owners this directly translates into a number of HRM practices. Firstly, the right to use the asset translates into participation in decisionmaking and the sharing of relevant information. Besides, employees might need training to learn how to participate in decision-making processes, and to learn understand information about the business. Also, as it is quite likely that consensus is not always easy to reach, a formal mechanism for resolving conflicts is a necessary HRM practice. 
Secondly, the right to the asset's returns translates into some form of profit-sharing. Thirdly, the right to sell the asset translates into participation in decision-making and sharing of information about the employee share ownership itself (Kaarsemaker 2006; Kaarsemaker/Poutsma 2006). The combination of employee share ownership with the mentioned HRM practices reflects actual "ownership" as it gives employees influence, information, and an opportunity for investment. This combination sends a consistent message to the employee that their ownership is a serious affair and that management takes them seriously as owners. Hence, psychological ownership is most likely to develop if employee share ownership is consistently combined with the mentioned HRM practices. It is also in this situation that it is most likely that individual feelings of ownership transform into a collective "ownership culture" (Kaarsemaker/ Poutsma 2006; cf. Bowen/Ostroff 2004).

\subsection{Firm-specific human capital}

\section{Definition}

One of the routes through which employees develop ownership feelings is through the investment of skills, time, ideas and energy in the company - in other words: through "self-investment." At work, employees get to know the company better, and they acquire knowledge, skills, and abilities that are specialized - in other words: employees obtain what Pierce and colleagues (2001, 2003) called "intimate knowledge." Intimate knowledge for example refers to knowing the right people, knowing how to get things done in the company, and it also refers to specialized substantive knowledge, skills, and abilities. Intimate knowledge is not easy to buy in the market. Knowledge, skills, and abilities that are not easy to replace, and that are of much higher value to the company than to other companies, are called firm-specific. Firm-specific human capital, because it is firm-specific and valuable to the company, is a source of sustained competitive advantage and therefore highly important to the firm (Barney/ Wright/Ketchen 2001; Barney 1991; Dierickx/Cool 1989).

\section{Ownership and control}

Firm-specific human capital, as a form of the co-specialization, works two ways: it makes employees with firm-specific knowledge, skills, and abilities dependent on the company, but the company also depends on these employees as source of sustained competitive advantage. Both the employees and the company bear risk. Firstly, employees with a relatively large amount of firm-specific knowledge, if they leave, will generally earn 15 to 25 percent less on their new jobs (Blair 1995, 1996, 1999). Secondly, returns on investments in firm-specific human capital are estimated to be "of the same order of magnitude as all of corporate profits" (i.e., at least 10 percent of the total wage bill of all for-profit companies [in the US] combined; see Blair 1999: 62). For this reason, Blair $(1995,1996,1999)$ argues for employee share ownership in exchange for employees' investments and the risks they bear. This would put employees on equal footing with shareholders in that they would get a say in decision-making processes in the company in which they have invested their specialized human capital, and in that they would share in the returns. 


\section{Risk}

Employee share ownership has been criticized by others, as employees cannot diversify their investments in firm-specific knowledge, skills, and abilities like distant shareholders can with their financial investments. This would mean that for example in case of bankruptcy, employees not only lose their jobs but also their investments in firm-specific human capital and the financial value of their employee shareholdings (cf., Benartzi et al. 2007; Meulbroek 2005; see Blasi/Kruse/Markowitz 2008 for a balanced discussion). However, this does not mean that all companies and all different appearances of employee share ownership can be put in one box and employee share ownership dismissed as generally too risky. The "risk" involved does not seem stop executives from holding shares in their employers and occasionally make (very) large profits. The level of risk depends on whether the employee share ownership substitutes for parts of normal salary and whether or not employees' pensions are dependent on their stakes in the company. Running the risk of losing one's job as such is not an argument against employee share ownership.

\section{Changing employment relationships}

I started this paper with the example of the mechanical engineering technology company that was considering the implementation of employee share ownership in order to attract and retain employees in a tight labour market. Investments in human capital in general are dependent on the state of labour markets (cf. Wasmer 2006). It becomes harder to retain employees if these employees feel they have sufficient opportunities to leave the company and get at least the same salary and benefits elsewhere, despite their firm-specific knowledge, skills, and abilities. In this situation, employees will not mind co-specializing, but companies need to work harder in order not to lose this mutual investment. The pertinence of this issue is heightened by the fact that employees do not take long-term relationships with companies for granted anymore, and are generally less committed to one employer (Tsui/Wu 2005). Employees have increasingly become "mobile investors" of their own human capital instead of "malleable resources" for the company (Gratton/Ghoshal 2003: 1). Employee share ownership can help rebalance the employment relationship and prevent under- or overinvestment in human capital, but instead stimulate mutual investment.

\section{Previous research}

Researchers have claimed that employees with firm-specific knowledge, skills, and abilities get higher compensation (e.g., Slaughter/Ang/Boh 2007), particularly if the related company resources involve more risk (e.g., Wang/Barney 2006). Empirical research has found that governance issues are maybe even more important than rewards (e.g., Griffith/Lusch 2007). Employee share ownership combines elements of both, and puts employees with firm-specific human capital investments on equal footing with shareholders who have financial investments in the company. There is not much research on the relationship between employee share ownership and firm-specific human capital. One study found no significant relationship between firm-specific human capital and employees' ESOP investment decisions (Degeorge et al. 2004), whereas another study found a significant positive relationship, which was interpreted 
as the safeguarding of firm-specific human capital investments through employee share ownership.

\section{Hypotheses}

The employees of the mechanical engineering technology company in the example at the beginning of this paper had highly specialized knowledge, skills, and abilities. Despite this, and despite high levels of ownership feelings for the company, they did not feel that it would be difficult for them to leave the company and either start for themselves or find a similar job elsewhere. The theoretical discussion shows that employee share ownership, combined with the discussed HRM practices, conveys the message that employees are taken seriously as co-owners of the business. Employee share ownership would give the employees in the example the desired influence in decisions that are of importance to them, as well as a share in the returns. In this way, employee share ownership might persuade employees with high levels of investments in firmspecific human capital, despite tight labour markets and a changing ethos as regards the employment relationship, to become more committed to the company. In companies currently without employee share ownership, giving employees the opportunity to become co-owners would transform high levels of psychological ownership into higher levels of organizational commitment of employees with significant firm-specific knowledge, skills, and abilities. In sum, I hypothesize the following:

Hypothesis 1. Employee share ownership has a positive effect on psychological ownership.

Hypothesis 2. Employee share ownership positively moderates the effect of employees' firm-specific human capital investments on organizational commitment.

\section{Methods}

\subsection{Sample and data}

Data are from questionnaires conducted among the workforce (including (top) management) of 11 (mainly) professional services firms: 289 employees in 3 companies without employee share ownership, and 488 employees in 8 companies with employee share ownership, including 283 employee owners. One of the companies is from the US, the others are Dutch. Most companies are relatively similar in size, with on average about 270 employees. Two surveys have been conducted in business units of larger companies, but these two business units are relatively independent from the larger companies and comparable with the other companies in the research on a number of indicators such as size, business activities and labour costs. None of the companies was listed on a stock exchange, apart from the holding company of one of the two business units. The majority of items in the questionnaires are statements with 7-point Likert scales to indicate the extent of (dis)agreement. There are some exceptions to prevent bias. The surveys have been conducted since 2004 and are part of a continuing project. The overall response rate for these surveys stands at 29 percent. Of the respondents, 59 percent are male. The distribution of employees according to job type is as follows: approximately 16 percent are administrative support staff, 4 percent production, maintenance, or delivery workers, 5 percent sales people, 58 percent profes- 
sional/technical staff, and 15 percent said they are part of management. All percentages are reasonably similar to the percentages found through interviews and annual reports, which confirms the representativeness of the sample.

\subsection{Independent variables}

\section{Firm-specific human capital investments}

This variable is often measured through a dummy variable, usually tenure. I chose not to do that as tenure is only a very crude measure. Tenure probably plays a more important role in the development of firm-specific knowledge, skills, and abilities at the beginning of a career than at later stages, when the relative amount of firm-specific human capital is more likely to remain constant while the substantive side becomes more important. Hence, I chose to measure this variable directly with the following overall single-item scale: "The special knowledge and skills that I have acquired at my current employer would have limited usefulness if I tried to apply it at another employer." As the table with descriptive statistics in the appendix shows, there is a low but significant correlation of this item with tenure $(.107 ; p<.01)$. In light of my above remarks, this does not seem to be counterintuitive. I am aware that single-item measures can be problematic. However, the measure I use here basically is a paraphrase of the definition of firm-specific human capital, and the construct itself seems sufficiently narrow and unidimensional to warrant the use of a single-item measure (cf. Scarpello/Campbell 1983; Wanous/Hudy 2001).

\section{Human resource management}

As discussed above, employee share ownership has the greatest effects on psychological ownership and beyond if combined with a number of other HRM practices: participation in decision-making, information-sharing, training to learn understand the business, a formal mechanism for resolving conflicts, and profit-sharing. For every single HRM practice several items are included in the survey. Factor analyses (exploratory and confirmatory) and further validity and reliability checks of the participation in decision-making items result in two scales for participation in decision-making: (1) participation in management, which refers to participation in decision-making about decisions close to employees, for example regarding their day-to-day work and working environment; and (2) participation in governance, which refers to participation in decision-making about issues that are more remote to employees, for example regarding the company as a whole, or collective bargaining agreements. The following statement is an example of a participation in management item: "This company encourages people to participate in decisions that affect their day-to-day work." An example of a participation in governance item is: "How much involvement and direct influence do YOU have in OVERALL company decisions?" Measures for the remaining HRM practices are all composed of multiple items. All scales have reasonable Cronbach's alpha reliability scores. An overall HRM measurement scale is created by averaging the sum of the scores on the single HRM-practice measurement scales. Cronbach's alpha for this scale is .83, and inter-item correlations range from .31 to .66, which indicates reasonable internal consistency of the HRM scale. 


\section{Employee share ownership}

Two measures of employee share ownership are used in the analyses. First, a dummy variable of whether the employee is working in a company with employee share ownership or not. Second, a dummy variable is created with the following item: "at present, do you still participate in the company [ESOP] and/or do you still own company stock?" Other measures such as an estimate of the value of the individual employees' stakes, though relevant (e.g., Culpepper et al. 2004; Pendleton/Wilson/Wright 1998) could unfortunately not be included in the questionnaires. However, the companies in this study are similar and the value of the individual employees' stakes is on average relatively modest and does not differ much between employees due to the institutional environment of the companies in this study. The financial value of the employee investments normally does not exceed a couple of thousand euros only. Hence, the mentioned two dummy variables should cover most of the effects of employee share ownership in the present study.

\subsection{Dependent variables}

Psychological ownership and organizational commitment are the dependent variables. Several items for measuring these variables have been included in the survey. The psychological ownership items stem from the work of Pierce and colleagues (e.g., Van Dyne/Pierce 2004) and from the Ownership Culture Survey ${ }^{3}$ (OCS). The organizational commitment items stem from the work of Meyer, Allen, and colleagues (e.g., Meyer/Allen 1991; Meyer/Allen/Smith 1993). Factor analyses (exploratory and confirmatory) and further validity and reliability checks of all these items together lead to three scales: (1) psychological ownership, which reflects employees' ownership feelings for the firm; (2) affective commitment, which reflects "a desire to maintain membership in the organization that develops largely as a result of work experiences that create feelings of comfort and personal competence" (Meyer/Allen 1991: 82); and (3) continuance commitment, which reflects "a need to remain, and results from recognition of the costs (...) associated with leaving" (Meyer/Allen 1991: 82-83). Only the OCS items are kept for the final psychological ownership scale. These two items reflect both individual ownership feelings and the extent to which the organizational culture can be labelled as an "ownership culture:" "how much do you feel like an owner of this company?" And: "how much do other people here feel like owners?" The other psychological ownership items have significant loadings on the affective commitment factor and are therefore removed.

\subsection{Control variables}

Employees are the unit of analysis in this study. I therefore made sure that the companies included in this study are similar on a number of relevant indicators. Nevertheless, company differences might influence the results. Therefore, company dummies have been included in the analysis, but no significant effect were found apart from the country differences (the US company versus the Dutch companies). As can be seen in

Developed by Ownership Associates in the US, and currently owned by the NCEO, also in the US. 
Table 2 in the results section, even this latter difference does not have a significant association in the final steps of the analysis. Overall, the inclusion of the company dummies does make the results of the analysis weaker, which is logical in light of the much lower power of the significance tests due to the larger number of variables. However, the conclusions remain the same. Therefore, I only report the analysis with just the country dummy as control variable (Dutch is the comparison group). Five further - employee-level - control variables are included in the analysis: tenure, age, gender (female is the comparison group), educational level, and job type. Five educational levels are distinguished - less than an associate degree is the comparison group, the other groups are: associate degree, BA/BSc degree, MA/MSc degree, and PhD. Finally, five job types are included. Administrative support staff is the comparison group, the other groups are: production/maintenance/delivery work, professional/technical staff, sales staff, and management.

\section{Results}

Multiple linear regression analysis is applied to test the hypotheses. Checks of the missing data for any patterns, checks of the assumptions for multiple linear regression, and checks of the residuals at the end of the regression analyses do not show any insurmountable problems. The firm-specific human capital investments variable deviated from normality and was transformed by taking the natural logarithm. The psychological ownership variable was also transformed to improve its properties and meet the assumptions more closely. Repeating the analyses with the original, nontransformed variables and with different estimation methods does not lead to different conclusions.

A table with descriptive statistics can be found in the appendix. Table 1 shows the regression results for psychological ownership. As said, psychological ownership mediates the effects of employee share ownership and should therefore be part of this kind of models that include employee share ownership. I therefore start with the regression analysis that has psychological ownership as the dependent variable. In the subsequent analysis with affective commitment as the dependent variable (shown in Table 2), psychological ownership is added to the model as a separate step in the analysis.

Even though firm-specific human capital investments are a form of selfinvestment by employees, adding this variable to the model in step 2 does not make a significant difference. This is a bit counterintuitive. As expected, and in line with Hypothesis 1, entering the HRM and employee share ownership variables into the equation yields positive and significant regression coefficients, and a higher coefficient of determination $\left(\Delta F=157.321, \Delta R^{2}=.179, p<.01\right.$, and $\Delta F=15.396, \Delta R^{2}=.017, p<$ .01 , respectively). The effect sizes are .285 and .028, which is normally labelled as medium and small, respectively, but that does not say so much about the practical significance of these findings (see Aguinis 2004; Aguinis/Beaty/Boik/Pierce 2005; Cohen 1988). The measure I am using in this regression analysis is current participation in the ESOP, as only this presumably leads to higher psychological ownership. 
Table 1 Results of regression analysis for psychological ownership

\begin{tabular}{|c|c|c|c|c|c|c|c|c|}
\hline Variables & \multicolumn{2}{|c|}{ Step 1} & \multicolumn{2}{|c|}{ Step 2} & \multicolumn{2}{|c|}{ Step 3} & \multicolumn{2}{|c|}{ Step 4} \\
\hline Step 1-Controls & $B$ & $S E$ & B & $S E$ & $B$ & $S E$ & $B$ & $S E$ \\
\hline (Constant) & $.942^{*+*}$ & .345 & $.957^{*+*}$ & .350 & $-1.603^{* * t}$ & .370 & $-1.480^{*+*}$ & .367 \\
\hline Age Group & $.341^{+4+t}$ & .086 & $.341^{+4+4}$ & .086 & .079 & .078 & .055 & .078 \\
\hline Tenure & $1.464 \mathrm{E}-5$ & 011 & .000 & .011 & .001 & .010 & -.003 & .010 \\
\hline Country & $1.559^{+* *+}$ & .203 & $1.565^{* * *}$ & .205 & $.971^{+4+t}$ & .187 & $.710^{4+*}$ & .196 \\
\hline Gender & $-.321^{* *}$ & .155 & $-.320^{* *}$ & .156 & -.178 & .138 & -.157 & .136 \\
\hline Education - Assoc & .485 & 299 & .496 & .301 & $.479^{*}$ & .266 & .410 & .263 \\
\hline Education - BA/BSc & $.444^{*}$ & .230 & $.444^{*}$ & .230 & .175 & .204 & .141 & 202 \\
\hline Education - MA/MSc & .217 & .245 & .216 & .245 & .071 & .217 & .062 & 214 \\
\hline Education - PhD & .950 & .587 & .947 & .587 & .323 & .521 & 291 & .514 \\
\hline Job type - Production & -.067 & .385 & -.053 & .389 & -.105 & .343 & -.113 & .339 \\
\hline Job type - Prof/Tech & .317 & .233 & .320 & .234 & $.370^{*}$ & .206 & $.371^{*}$ & .204 \\
\hline Job type - Sales & .503 & .403 & .496 & .404 & .488 & .357 & .507 & .352 \\
\hline Job type - Mgmt & $.468^{*}$ & .271 & $.465^{*}$ & .272 & .182 & .241 & .116 & .238 \\
\hline $\begin{array}{l}\text { Step 2-Firm-specific human } \\
\text { capital investments } X\end{array}$ & & & -.032 & 110 & .037 & .097 & .002 & .096 \\
\hline $\begin{array}{l}\text { Step 3-Human resource } \\
\text { management } Z_{1}\end{array}$ & & & & & $.825^{5 * *}$ & .066 & $.793^{3+x}$ & .065 \\
\hline $\begin{array}{l}\text { Step 4-Employee share } \\
\text { ownership } Z_{2}\end{array}$ & & & & & & & $.543^{*+*}$ & .138 \\
\hline$R^{2}$ & $.192^{4+*}$ & & .193 & & $.372^{4+4}$ & & $.389^{*+*}$ & \\
\hline Adjusted $R^{2}$ & .175 & & .174 & & .356 & & .372 & \\
\hline Change in $R^{2}$ & 192 & & .000 & & .179 & & .017 & \\
\hline$F$ for change in $R^{2}$ & $11.004^{\text {tat }}$ & & .084 & & $157.321^{\text {*t** }}$ & & $15.396^{4+4}$ & \\
\hline
\end{tabular}

Listwise $N=567 .{ }^{\prime \prime *} p<.01, "{ }^{\prime \prime} p<.05, " p<.10$.

Table 2 shows the regression results for affective commitment. Adding firm-specific human capital investments to the model in step 2 does not make a significant difference. The regression coefficient is even negative, though very small. Entering the HRM variable into the equation again yields a positive and significant regression coefficient, and a higher coefficient of determination $\left(\Delta F=187.445, \Delta R^{2}=.222, p<.01\right.$, effect size $=.356$ ), but entering employee share ownership does not.

This time, I am using the employee share ownership measure that indicates whether the company offers the employees the opportunity to become employee shareholders or not. Hypothesis 2 does not say that employees have to be actual participants in an ESOP. As I found in the mechanical engineering company that I visited, employees are very positive about employee share ownership, but, for whatever reasons, they do not always and immediately like to become actual employee shareholders or be forced to do so. Therefore I am using the less strict measure in the current regression analysis with affective commitment as the dependent variable.

Adding psychological ownership to the model in step 5 produces a positive and significant regression coefficient. Also, the coefficient of determination increases significantly $\left(\Delta F=25.884, \Delta R^{2}=.029, p<.01\right)$. The effect size is .049. And entering the 
Table 2: Results of regression analysis for affective commitment

\begin{tabular}{|c|c|c|c|c|c|c|c|c|c|c|c|c|}
\hline \multirow{2}{*}{$\begin{array}{l}\text { Variables } \\
\text { Step 1-Controls }\end{array}$} & \multicolumn{2}{|c|}{ Step 1} & \multicolumn{2}{|c|}{ Step 2} & \multicolumn{2}{|c|}{ Step 3} & \multicolumn{2}{|c|}{ Step 4} & \multicolumn{2}{|c|}{ Step 5} & \multicolumn{2}{|c|}{ Step 6} \\
\hline & $B$ & $S E$ & $B$ & $S E$ & $B$ & $S E$ & $B$ & $S E$ & $B$ & $S E$ & $B$ & $S E$ \\
\hline (Constant) & $3.830^{4+1+}$ & .307 & $3.865^{\text {tot }}$ & .311 & $1.389^{+*+1}$ & .323 & $1.426^{\text {tot }}$ & .323 & $1.718^{+t+1}$ & .321 & $1.881^{\text {tot }}$ & .324 \\
\hline Age Group & $.234^{*+*}$ & .077 & $.235^{+*+1}$ & .077 & -.005 & .069 & -.014 & .069 & -.029 & .067 & -.028 & .067 \\
\hline Tenure & .009 & .010 & .009 & .010 & .008 & .009 & .007 & .009 & .008 & .009 & .007 & .009 \\
\hline Country & $.989^{9+*}$ & .181 & $1.004^{+*+1}$ & .182 & $.415^{*}$ & .163 & $.323^{*}$ & .174 & .206 & .171 & .168 & .171 \\
\hline Gender & $-.320^{*}$ & .142 & $-.316^{* *}$ & .142 & -.201 & .123 & -.196 & .122 & -.156 & .120 & -.128 & .119 \\
\hline Education - Assoc & .244 & .264 & .270 & .266 & .261 & .229 & .237 & .229 & .157 & .224 & .114 & .223 \\
\hline Education - BA/BSc & .143 & .206 & .144 & .206 & -.079 & .178 & -.090 & .177 & -.125 & .174 & -.120 & .172 \\
\hline Education - MA/MSc & .009 & .218 & .006 & .218 & -.125 & .188 & -.130 & .187 & -.143 & .183 & -.118 & .182 \\
\hline Education - PhD & -.104 & .518 & -.110 & .519 & -.723 & .448 & -.737 & .448 & $-.793^{*}$ & .438 & -.687 & .436 \\
\hline Job type - Production & -.027 & .342 & .006 & .345 & -.022 & .296 & -.020 & .296 & -.007 & .289 & -.052 & .288 \\
\hline Job type - Prof/Tech & -157 & .211 & -.152 & .211 & -.069 & .181 & -.063 & .181 & -.135 & .178 & -.090 & .177 \\
\hline Job type - Sales & -.262 & .378 & -.274 & .379 & -.279 & .325 & -.262 & .325 & -.389 & .319 & -.339 & .317 \\
\hline Job type - Mgmt & .153 & .243 & .146 & .243 & -.126 & .210 & -.145 & .210 & -.165 & .205 & -.129 & .204 \\
\hline $\begin{array}{l}\text { Step 2-Firm-specific hu- } \\
\text { man capital investments } X\end{array}$ & & & -.074 & .098 & -.012 & .085 & -.026 & .085 & -.021 & .083 & $-.225^{*+}$ & .109 \\
\hline $\begin{array}{l}\text { Step 3-Human re- } \\
\text { source management } Z_{1}\end{array}$ & & & & & $.792^{2 * *}$ & .058 & $.783^{*+1}$ & .058 & $.633^{+*+1}$ & .064 & $.589^{9+1}$ & .065 \\
\hline $\begin{array}{l}\text { Step 4-Employee } \\
\text { share ownership } Z_{2}\end{array}$ & & & & & & & .185 & .125 & .061 & .124 & -.055 & .130 \\
\hline $\begin{array}{l}\text { Step 5-Psychological } \\
\text { ownership } Y_{1}\end{array}$ & & & & & & & & & $.189^{\circ+*}$ & .037 & $.177^{+3}$ & .037 \\
\hline $\begin{array}{l}\text { Step 6-Firm-specific hu- } \\
\text { man capital investments } \times \\
\mathrm{HRM} \times \text { Employee share } \\
\text { ownership } X \cdot Z_{1} \cdot Z_{2}\end{array}$ & & & & & & & & & & & $.027^{7+3}$ & .010 \\
\hline$R^{2}$ & $.153^{+*+}$ & & .154 & & $.376^{* * *}$ & & .378 & & $.407^{*+m}$ & & $.417^{+*}$ & \\
\hline Adjusted $R^{2}$ & .133 & & .133 & & .359 & & .361 & & .389 & & .398 & \\
\hline Change in $R^{2}$ & .153 & & .001 & & .222 & & .003 & & .029 & & .009 & \\
\hline$F$ for change in $R^{2}$ & $7.946^{t+1}$ & & .570 & & $187.445^{+*+1}$ & & 2.192 & & $25.884^{4+1+}$ & & $8.327^{+* *+1}$ & \\
\hline
\end{tabular}

Listwise $N=542 .{ }^{* * *} p<.01,{ }^{* *} p<.05,{ }^{*} p<.10$.

interaction term ${ }^{4}$ in step 6 again yields positive and significant results $(\Delta F=8.327$, $\left.\Delta R^{2}=.009, p<.01\right)$. The effect size of this step is small as well, .015, but as said, that is absolutely not uncommon and does not mean much in practical terms (Aguinis et al. 2005). What also happens in step 6 is that the (negative) regression coefficient for firm-specific human capital investments becomes significant $(p<.05)$. All these findings are support for Hypothesis 2 as far as affective commitment is concerned.

The regression analysis with continuance commitment as the dependent variable (table not shown here) reveals a positive and significant regression coefficient in step 2 where the firm-specific human capital investments variable is added to the model $(\Delta F$

4 The interaction term is the product of the firm-specific human capital investments variable, the HRM variable, and the employee share ownership variable. This term expresses that the direct effects of firm-specific human capital investments are influenced or "moderated" by the combination of employee share ownership and related HRM practices, and is added as an extra step to the analysis after the single variables that compose the interaction term have been entered. 
$=9.266, \Delta R^{2}=.014, p<.01$, effect size $\left.=.017\right)$. Also, steps 4 to 6 show only nonsignificant changes. Nevertheless, this is not counterintuitive given the meaning of continuance commitment as a slightly negative form of organizational commitment. "Costs" involved with leaving can keep employees with the company. Firm-specific human capital investments can be such a cost, but less so in tight labour markets. Employee share ownership does not have an effect here.

In sum, Hypothesis 1 is confirmed: employee share ownership has a positive effect on psychological ownership. For affective commitment, Hypothesis 2 is corroborated by the present dataset and analyses as well. On the one hand, employees' firmspecific human capital investments have a significant negative effect on affective commitment. On the other hand, employee share ownership does positively moderate the effect of employees' firm-specific human capital investments on affective commitment. Employee share ownership therefore helps transform high levels of psychological ownership among employees with firm-specific knowledge, skills, and abilities into higher levels of affective commitment. Hypothesis 2 is rejected as regards continuance commitment.

\section{Discussion and conclusions}

Nowadays, with many companies experiencing tight labour markets for the employees they need, and employees as "mobile investors" of human capital, employees feel less bound to a particular company even if they have strong feelings of ownership for that company. The present study shows that employee share ownership might be a fruitful avenue in dealing with this issue. It appears that if companies offer employees with firm-specific knowledge, skills, and abilities the opportunity to become co-owners of the company, these employees are more likely to come to feel a positive desire to maintain their membership of the company. At the same time, there is no evidence that employee share ownership makes it harder for employees to leave the company due to a (negative) perception of higher costs of leaving. All this presumes that employee share ownership is taken seriously by the company, as reflected by the presence of HRM practices such as certain participation in decision-making practices, information-sharing, training for business literacy, a formal mechanism for the resolution of conflicts, and profit-sharing.

Among the limitations of the present study are that the data stem from employees in a relatively small number of companies only. Moreover, the majority of the companies operate in the professional services sector, and the most of the companies are Dutch. This limits the extent to which the conclusions can be generalized. Although the study is set up in a way to keep contextual variables constant as much as feasible, it cannot be entirely ruled out that certain variables have been omitted that should really have been included. Also, the data are cross-sectional, so definite causal inferences cannot be established. The effects, however, are assumed to exist on the basis of strong theoretical considerations.

As this is only a simple and very straightforward study, it should probably be regarded as exploratory and as an initial impetus to further research on the link between firm-specific human capital investments and employee share ownership. The measures of firm-specific human capital investments and of employee share ownership I use in 
the present study are simple and straightforward. This does not do right by the complexity of these constructs. The role and meaning of firm-specific human capital investments in the HRM context of companies should be further investigated, as well as the link with other aspects of employee share ownership such as the level of the financial stakes, and individual risk preferences.

With this study, I demonstrate that employee share ownership can play a positive role in building and keeping firm-specific human capital. Affective commitment of employees with firm-specific knowledge, skills, and abilities tends to be higher if companies give them the opportunity to become shareholders. Clearly more research is necessary, but this finding points out to managers a worthwhile avenue for attracting and retaining firm-specific human capital investments despite tight labour markets and changing employment relationships.

\section{References}

Aguinis, H. (2004): Regression analysis for categorical moderators. New York: The Guilford Press.

Aguinis, H./Beaty, J.C./Boik, R.J./Pierce, C.A. (2005): Effect size and power in assessing moderating effects of categorical variables using multiple regression: a 30-year review. In: Journal of Applied Psychology, 90(1): 94-107.

Bakan, I./Suseno, Y./Pinnington, A./Money, A. (2004): The influence of financial participation and participation in decision-making on employee job attitudes. In: International Journal of Human Resource Management, 15(3): 587-616.

Barney, J./Wright, M./Ketchen, D.J. (2001): The resource-based view of the firm: ten years after 1991. In: Journal of Management, 27: 625-641.

Barney, J.B. (1991): Firm resources and sustained competitive advantage. In: Journal of Management, 17(1): 99-120.

Benartzi, S./Thaler, R.H./Utkus, S.P./Sunstein, C.R. (2007): The law and economics of company stock in 401(k) plans. In: Journal of Law \& Economics, 50(1): 45-79.

Blair, M.M. (1995): Ownership and control: rethinking corporate governance for the twenty-first century. Washington, DC: The Brookings Institution.

Blair, M.M. (1996): Wealth creation and wealth sharing: a colloquium on corporate governance and investments in human capital. Washington, DC: The Brookings Institution.

Blair, M.M. (1999): Firm-specific human capital and theories of the firm. In: M.M. Blair/M.J. Roe (eds.): Employees and corporate governance. Washington, DC: Brookings Institution Press: 58-90.

Blasi, J./Conte, M./Kruse, D. (1996): Employee stock ownership and corporate performance among public companies. In: Industrial and Labor Relations Review, 50(1): 60-79.

Blasi, J.R./Freeman, R.B./Mackin, C./Kruse, D.L. (2008): Creating a bigger pie? The effects of employee ownership, profit sharing, and stock options on workplace performance. Cambridge, MA: NBER.

Blasi, J.R./Kruse, D.L./Markowitz, H.M. (2008): Risk and lack of diversification under employee ownership and shared capitalism. Cambridge, MA: NBER.

Bowen, D.E./Ostroff, C. (2004): Understanding HRM-firm performance linkages: the role of the "strength" of the HRM system. In: Academy of Management Review, 29(2): 203-221.

CIPD. (2006): Employee share plans: supporting business performance. London: Chartered Institute of Personnel and Development.

Cohen, J. (1988): Statistical power analysis for the behavioral sciences (2nd ed.). Hillsdale, NJ: Erlbaum.

Conte, M.A./Svejnar, J. (1990): The performance effects of employee ownership plans. In: A.S. Blinder (ed.): Paying for productivity: a look at the evidence. Washington, DC: The Brookings Institution: 143-172.

Culpepper, R.A./Gamble, J.E./Blubaugh, M.G. (2004): Employee stock ownership plans and threecomponent commitment. In: Journal of Occupational and Organizational Psychology, 77: 155-170.

De Jong, G./Van Witteloostuijn, A. (2004): Successful corporate democracy: sustainable cooperation of capital and labor in the Dutch Breman Group. In: Academy of Management Executive, 18(3): 54-66.

Degeorge, F./Jenter, D./Moel, A./Tufano, P. (2004): Selling company shares to reluctant employees: France Telecom's experience. In: Journal of Financial Economics, 71: 169-202. 
Dierickx, I./Cool, K. (1989): Asset stock accumulation and sustainability of competitive advantage. In: Management Science, 35(12): 1504-1511.

Gratton, L./Ghoshal, S. (2003): Managing personal human capital: new ethos for the 'volunteer' employee. In: European Management Journal, 21(1): 1-10.

Griffith, D.A./Lusch, R.F. (2007): Getting marketers to invest in firm-specific capital. In: Journal of Marketing, 71(1): 129-145.

Kaarsemaker, E.C.A. (2006): Employee ownership and human resource management: a theoretical and empirical treatise with a digression on the Dutch context. Doctoral Dissertation, Radboud University Nijmegen, Nijmegen.

Kaarsemaker, E.C.A./Poutsma, E. (2006): The fit of employee ownership with other human resource management practices: theoretical and empirical suggestions regarding the existence of an ownership high-performance work system. In: Economic and Industrial Democracy, 27(4): 669-685.

Kalmi, P./Pendleton, A./Poutsma, E. (2005): Financial participation and performance in Europe. In: Human Resource Management Journal, 15(4): 54-67.

Kruse, D. (2002): Research evidence on the prevalence and effects of employee ownership. In: Journal of Employee Ownership Law and Finance, 14(4): 65-90.

Kruse, D./Blasi, J. (1995): Employee ownership, employee attitudes, and firm performance. Cambridge, MA: National Bureau of Economic Research.

Maaløe, E. (1998): The employee owner: organizational and individual change within manufacturing companies as participation and sharing grow and expand. Copenhagen: Academic Press.

Meulbroek, L. (2005): Company stock in pension plans: how costly is it? In: Journal of Law \& Economics, 48(2): 443-474.

Meyer, J.P./Allen, N.J. (1991): A three-component conceptualization of organizational commitment. In: Human Resource Management Review, 1(1): 61-89.

Meyer, J.P./Allen, N.J./Smith, C.A. (1993): Commitment to organizations and occupations: extension and test of a three-component conceptualization. In: Journal of Applied Psychology, 78(4): 538-551.

Pendleton, A. (2001): Employee ownership, participation and governance: a study of ESOPs in the UK. London and New York: Routledge.

Pendleton, A./Wilson, N./Wright, M. (1998): The perception and effects of share ownership: empirical evidence from employee buy-outs. In: British Journal of Industrial Relations, 36(1): 99-123.

Pierce, J.L./Kostova, T./Dirks, K.T. (2001): Toward a theory of psychological ownership in organizations. In: Academy of Management Review, 26(2): 298-310.

Pierce, J.L./Kostova, T./Dirks, K.T. (2003): The state of psychological ownership: integrating and extending a century of research. In: Review of General Psychology, 7(1): 84-107.

Rosen, C./Case, J./Staubus, M. (2005): Equity: why employee ownership is good for business. Boston, MA: Harvard Business School Press.

Scarpello, V./Campbell, J.P. (1983): Job satisfaction: are all the parts there? In: Personnel Psychology, 36: $577-600$.

Sengupta, S./Whitfield, K./McNabb, B. (2007): Employee share ownership and performance: golden path or golden handcuffs? In: International Journal of Human Resource Management, 18(8): 1507-1538.

Slaughter, S.A./Ang, S./Boh, W.F. (2007): Firm-specific human capital and compensation organizational tenure profiles: an archival analysis of salary data for it. In: Human Resource Management, 46(3): 373-394.

Tsui, A.S./Wu, J.B. (2005): The new employment relationship versus the mutual investment approach: implications for human resource management. In: Human Resource Management, 44(2): 115-121.

Van Dyne, L./Pierce, J.L. (2004): Psychological ownership and feelings of possession: three field studies predicting employee attitudes and organizational citizenship behavior. In: Journal of Organizational Behavior, 25: 439-459.

Wang, H.C./Barney, J.B. (2006): Employee incentives to make firm-specific investments: implications for resource-based theories of corporate diversification. In: Academy of Management Review, 31(2): 466-476.

Wanous, J.P./Hudy, M.J. (2001): Single-item reliability: a replication and extension. In: Organizational Research Methods, 4(4): 361-375.

Wasmer, E. (2006): General versus specific skills in labor markets with search frictions and firing costs. In: American Economic Review, 96(3): 811-831. 


\section{Appendix}

\section{Table A1: Descriptive statistics}

\begin{tabular}{|c|c|c|c|c|c|c|c|c|c|c|c|c|c|c|c|c|c|c|c|}
\hline$\stackrel{\infty}{\varnothing}$ & & & & & & & & & & & & & & & & & & & $\frac{1}{8}$ \\
\hline$\approx$ & & & & & & & & & & & & & & & & & & $\frac{1}{9}$ & 寠 \\
\hline$\cong$ & & & & & & & & & & & & & & & & & $\frac{1}{6}$ & $\stackrel{1}{1}$ & ${ }_{8}^{1}$ \\
\hline$\stackrel{L}{L}$ & & & & & & & & & & & & & & & & 产 & 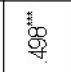 & 寈 & 畓 \\
\hline$\forall$ & & & & & & & & & & & & & & & s. & $\frac{\mathrm{g}}{\mathrm{g}}$ & 突 & $\stackrel{10}{50}$ & 洁 \\
\hline$\stackrel{๗}{\rightleftharpoons}$ & & & & & & & & & & & & & & @) & 寊 & $\stackrel{\frac{1}{6}}{\frac{10}{6}}$ & $\frac{5}{6}$ & 8 & 8 \\
\hline$\simeq$ & & & & & & & & & & & & & 8 & 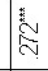 & ำ & 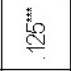 & s。 & $\begin{array}{l}\text { 类 } \\
\stackrel{2}{c}\end{array}$ & $\begin{array}{l}\text { so } \\
\end{array}$ \\
\hline 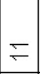 & & & & & & & & & & & & 多 & go & (8) & 封 & \% & $\mathscr{8}$ & $\stackrel{\mathrm{m}}{\stackrel{2}{\circ}}$ & f \\
\hline 으 & & & & & & & & & & & 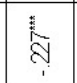 & $\stackrel{5}{8}$ & $\frac{L}{5}$ & 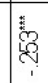 & $\stackrel{1}{6}$ & 葊 & 善 & 告 & है \\
\hline$\sigma$ & & & & & & & & & & 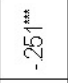 & 웜 & $\stackrel{y}{\circ}$ & 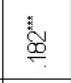 & $\stackrel{10}{0}$ & s。응 & $\begin{array}{l}\text { to } \\
\stackrel{5}{\circ}\end{array}$ & $\frac{1}{\grave{i}}$ & $\grave{m}_{i}^{\frac{m}{b}}$ & 守 \\
\hline$\infty$ & & & & & & & & & $\stackrel{8}{8}$ & 导 & $\underset{1}{8}$ & $\stackrel{\varrho}{\zeta}$ & ఫ্ & 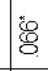 & 8 & 惫 & 8 & $\stackrel{\leftrightarrow}{8}$ & 8 \\
\hline$N$ & & & & & & & & $\stackrel{8}{\circ}$ & $\stackrel{1}{\stackrel{1}{*}}$ & $\frac{1}{m}$ & $\underset{7}{\mathrm{~g}}$ & $\bar{\delta}_{i}$ & $\underset{i}{\stackrel{5}{ \pm}}$ & $\frac{1}{6}$ & 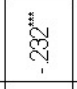 & $\begin{array}{l}8 \\
\stackrel{8}{8} \\
1\end{array}$ & 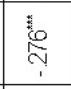 & $\underset{\mathrm{N}}{\stackrel{2}{\mathrm{~N}}}$ & $\underset{⿱ 乛}{\stackrel{2}{2}}$ \\
\hline$\bullet$ & & & & & & & 8 & : & $\stackrel{\text { o }}{\stackrel{2}{\circ}}$ & 氶 & 8 & 8 & 임 & $\$$ & 落 & $\stackrel{ \pm}{5}$ & 8 & 驾 & 8 \\
\hline مـا & & & & & & 旁 & 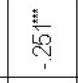 & 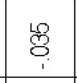 & 을 & $\frac{5}{5}$ & $\stackrel{\infty}{\zeta_{i}}$ & 8 & $\stackrel{5}{\infty}$ & $\frac{\varrho}{0}$ & N & 声 & స్ & 뇽 & $\begin{array}{l}6 \\
8 \\
\end{array}$ \\
\hline$\checkmark$ & & & & & 8 & o. & $\stackrel{\infty}{8}$ & 8 & $\begin{array}{l}1 \\
8\end{array}$ & $\stackrel{1}{\frac{1}{0}}$ & ฮ్ర & స్. & go & 电 & $\stackrel{\Delta}{8}$ & $\frac{5}{7}$ & 导 & $\bar{亏}_{i}$ & 8 \\
\hline m & & & & 8 & $\stackrel{5}{80}$ & वै & 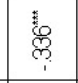 & 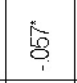 & $\stackrel{1}{E}$ & 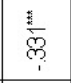 & d & $\frac{1}{m}$ & $\stackrel{\text { s. }}{\stackrel{5}{\rightleftarrows}}$ & 热 & $\begin{array}{l}\text { 尊 } \\
\text { 焉 }\end{array}$ & $\begin{array}{l}\frac{1}{0} \\
\text { d } \\
\end{array}$ & 毒 & $\begin{array}{l}1 \\
8 \\
\infty\end{array}$ & క్లి \\
\hline$\sim$ & & & 惫 & 은 & $\stackrel{\text { g g }}{g}$ & $\stackrel{\circ}{\circ}$ & 总 & 8 & $\stackrel{m}{\stackrel{m}{c}}$ & $\stackrel{5}{\stackrel{L}{L}}$ & \& & $\stackrel{p}{\stackrel{2}{*}}$ & $\stackrel{1}{\stackrel{1}{\circ}}$ & N & 兽 & 曽 & : & 过 & $\stackrel{1}{\stackrel{2}{\circ}}$ \\
\hline- & & 营 & $\stackrel{2}{2}$ & 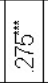 & $\mathscr{8}$ & $\stackrel{\infty}{\frac{\infty}{\zeta}}$ & 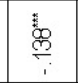 & 웅 & 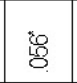 & $\stackrel{8}{8}$ & 8 & 莺 & \& & 落 & 总 & $\stackrel{1}{\stackrel{1}{厂}}$ & $\underset{N}{ }$ & $\frac{\mathrm{L}}{\mathrm{L}}$ & $\stackrel{1}{\bar{N}}$ \\
\hline 8 & 市 & $\stackrel{N}{\check{N}}$ & 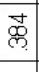 & 吉 & 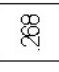 & f & 多 & $\bar{N}$ & है & gु & $\underset{Ð}{\Phi}$ & $\stackrel{\infty}{\infty}$ & $\frac{\mathscr{O}}{6}$ & $\stackrel{8}{-}$ & $\begin{array}{l}\infty \\
\text { 焉 }\end{array}$ & $\bar{g}$ & $\begin{array}{l}\text { g } \\
\infty \\
\end{array}$ & $\stackrel{?}{\circ}$ & $\stackrel{\text { f }}{\leftarrow}$ \\
\hline \begin{tabular}{|l|}
$\mathbb{1}$ \\
$\stackrel{\mathbb{N}}{2}$ \\
\end{tabular} & $\begin{array}{l}\bar{m} \\
\end{array}$ & 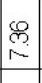 & $\stackrel{\infty}{\stackrel{\infty}{\longrightarrow}}$ & 8 & g & m & g & $\delta$ & t & 趈 & t & 8 & 8 & 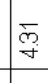 & or & 8 & $\begin{array}{l}\bar{\sigma} \\
\varnothing \\
\end{array}$ & $\Sigma_{i}$ & 志 \\
\hline $\mid$ & $\mid$ & 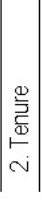 & 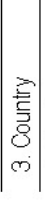 & $\left|\begin{array}{l|}\overline{\mathrm{d}} \\
\overline{\mathrm{c}} \\
\mathrm{d} \\
\mathrm{D} \\
\dot{\mathrm{j}}\end{array}\right|$ & 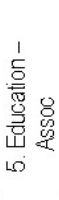 & 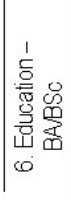 & 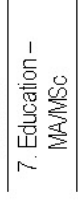 & 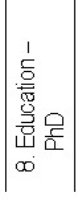 & 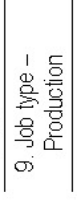 & 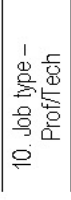 & 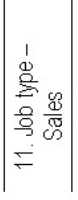 & 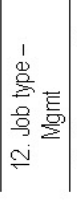 & 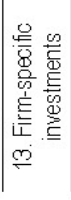 & 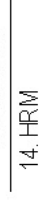 & 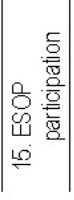 & 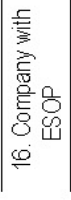 & 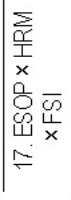 & 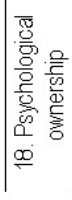 & 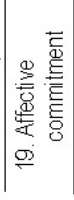 \\
\hline
\end{tabular}

